ЦЕХАН Д.М.

\title{
ЗЛОЧИННІСТЬ У МІСЦЯХ ПОЗБАВЛЕННЯ ВОЛІ ЯК СИСТЕМА
}

У статті окреслені основні теоретичні підходи до кримінологічного розуміння злочинності як соціального феномену та охарактеризовано інноваційні підходи щодо розуміння злочинності крізь призму інституційного підходу, а також злочинності як відповідної соціальної системи, для якої характерна своя структурна побудова та відповідна система взаємозв'язків між елементами. Обгрунтовано доцільність застосування системного підходу для пояснення сутності злочинності в місцях позбавлення волі, зважаючи на особливості території іï функціонування та особливі елементи ії структури.

Визначено основні термінологічні конструкції, які використовуються для позначення злочинності засуджених, а також звернута увага, що дослідниками не досягнуто єдності щодо розуміння системи злочинів, які необхідно включати до структури злочинності в місцях позбавлення волі. Охарактеризовано основні положення щодо розуміння злочинності як системи, які окреслені в межах кримінології. Проаналізовано аргументи прибічників та противників розуміння злочинності як системи та підтримано методологічну концепцію розуміння злочинності в місцях позбавлення волі як відповідної системи. Визначено основні ознаки, які характеризують системи різного рівня складності з можливістю їх подальшої екстраполяції для пояснення злочинності в місцях позбавлення волі як системи. Встановлено структурні елементи злочинності в місцях позбавлення волі як системи, зокрема злочинну діяльність осіб, які відбувають кримінальне покарання, злочинність персоналу установ виконання покарань, а також інфраструктуру злочинності в місцях позбавлення волі. Виокремлено складові частини злочинної діяльності осіб, які відбувають кримінальне покарання. Охарактеризовано окремі показники динаміки злочинності засуджених у місцях позбавлення волі.

Виокремлено злочинність персоналу органів та установ виконання покарань як елемента системи злочинності в місцях позбавлення волі. Визначено особливі характеристики корупційної злочинності як складової частини злочинності в місцях позбавлення волі, зокрема визначено, що корупційна злочинність персоналу установ виконання кримінальних покарань може визначатись як складова частина злочинності в місцях позбавлення волі лише крізь призму відносин «персонал установи -засуджені». Сформульовано визначення інфраструктури злочинності як елемента досліджуваної системи. Крізь призму ознак, які характеризують системи, обгрунтовано розуміння злочинності в місцях позбавлення волі як системи.

Ключові слова: злочинність, злочинність у місиях позбавлення волі, злочинність засуджених, злочинність персоналу місиь позбавлення волі, інфраструктура злочинності, системний підхід, система.

The article outlines the basic theoretical approaches to criminological understanding of crime as a social phenomenon, and describes innovative approaches to understanding crime through the prism of an institutional approach, as well as crime as an appropriate social system characterized by its structural construction and appropriate system of interconnections. The expediency of applying a systematic approach for explaining the nature of crime in prisons is justified, taking into account the peculiarities of the territory of its functioning and the particular elements of its structure.

The basic terminological constructs that are used to refer to the convicts' crime are defined, as well as the attention that the researchers have not reached a unity in under-

(C) ЦЕХАН Д.М. - кандидат юридичних наук, доцент, доцент кафедри криміналістики (Національний університет «Одеська юридична академія») 
standing the system of crimes that should be included in the structure of crime in prisons. The main provisions for understanding crime as a system are outlined within criminology. The arguments of supporters and opponents of understanding crime as a system are analyzed and the methodological concept of understanding crime in prisons as a relevant system is supported. The main features that characterize systems of varying levels of complexity with the possibility of their further extrapolation to explain crime in prisons as a system are identified. Structural elements of crime in prisons have been identified as a system, including the criminal activity of persons serving criminal sentences, the criminality of staff of penitentiary institutions, and the crime infrastructure in prisons. The components of criminal activity of persons serving a criminal sentence are separated. Some indicators of the dynamics of crime convicted in prisons are described.

The crime of the staff of the bodies and institutions of execution of penalties as an element of the system of crime in the places of imprisonment is distinguished. Specific characteristics of corruption crime as a component of crime in prisons are determined, in particular it is determined that corruption crime of the staff of the institutions of execution of criminal penalties can be defined as a component of crime in places of imprisonment only through the prism of relations of the staff of the prison institution. The definition of crime infrastructure as an element of the system under investigation is formulated. Through the prism of features that characterize systems, an understanding of crime in prisons as a system is substantiated.

Key words: crime, crime in places of imprisonment, crime of convicts, crime of staff of places of imprisonment, infrastructure of crime, systematic approach, system.

Вступ. Усебічність та об'єктивність будь-якого наукового дослідження вимагає визначення аксіоматики, основних наукових категорій, які $€$ його основою, оскільки навколо них і формується розвиток наукових положень та ідей. Практика засвідчує, що плутанина у визначеннях у наукових дослідженнях часто призводить до непорозуміння, хибності висновків $\mathrm{i}$, що особливо важливо для наук юридичного циклу, до неточного використання їх у законодавстві. Будь-яка наука, як слушно наголошує М.I. Кондаков, має виступати у вигляді чіткої системи понять, в якій усі поняття пов'язані між собою та становлять частини одного ланцюжка [7]. У зв'язку із цим одним із найважливіших завдань теорії оперативно-розшукової діяльності як системи знань виступає вдосконалення її понятійно-категоріального апарату й розкриття змісту вихідних понять [12].

Особливої актуальності це питання набуває в міждисциплінарних дослідженнях, які виконуються в межах теорії оперативно-розшукової діяльності та характеризуються необхідністю використання понятійно-категоріального апарату, який розроблений суміжними науками кримінально-правового циклу.

Постановка завдання. Метою статті є обгрунтування злочинності в місцях позбавлення волі як системи.

Результати дослідження. Зважаючи на об'єкт представленого дослідження, науковою категорією, яка потребує системного аналізу та визначення сутності, є «злочинність у місцях позбавлення волі». Безумовно, в даному випадку початковим та системоутворюючим $є$ поняття злочинності, яке сформовано в межах кримінології та грунтовно проаналізовано вченими-кримінологами, що дозволяє залишити поза увагою аналіз цього поняття в межах представленої роботи та розпочати аналіз похідних категорій більш нижчого рівня, зокрема «злочинності в місцях позбавлення волі». Перш за все, принагідно відзначити, що в межах наук кримінально-правового циклу для позначення злочинності засуджених, які відбувають покарання в установах виконання покарань, використовуються терміни «пенітенціарна злочинність» та «злочинність у місцях позбавлення волі». При цьому спостерігається відповідна тенденція щодо використання терміна «пенітенціарна злочинність» у межах кримінології, а терміна «злочинність у місцях позбавлення волі» - науковцями в галузі кримінально-виконавчого права.

Аналіз кримінологічних досліджень останніх років свідчить, що вченими-кримінологами постійно здійснюється пошук нових методологічних підходів щодо розуміння злочинності, які здатні забезпечити глибше наукове пізнання та розуміння цього явища, що зазнало суттєвої трансформації за останні десятиліття. Так, серед інноваційних підходів слушно виокремити розуміння злочинності як системи, хоча такий підхід визнається не усіма дослідниками, які відзначають, що визнавати злочинність системою не має достатніх підстав. Злочинність, на їхню думку, не позбавлена елементів стихійності, зв'язок між злочинами в більшості випадків від- 
сутній, окремі компоненти злочинності не утворюють взаємопов'язаних елементів цілісної системи. Злочинність у суспільстві зберігається, існує не внаслідок саморозвитку, що характерно для систем, а в силу дії інших зовнішніх для неї обставин - причин та умов, які витікають із конкретно-історичних особливостей життя суспільства [1]. Наведена позиція, на нашу думку, $\epsilon$ доволі дискусійною, оскільки фактично побудована на запереченні усталеної у кримінологічній науці концепції самовідтворення злочинності і характеризує їі як явище, яке змінюють виключно зовнішні фактори - причини та умови, в той час як сучасна злочинність, характеризуючись адаптивністю, використовує свої внутрішні механізми для пристосування до конкретних історичних умов розвитку суспільства, що характерно для всіх соціальних систем, а в окремих випадках здійснює вплив на соціальні процеси та інституції, які визначають суспільний розвиток у межах конкретного історичного періоду.

Можна повністю солідаризуватись із позицією М.А. Сутуріна, який відзначає, що злочинність, виступаючи як складна соціальна система, характеризується як внутрішньоструктурними властивостями, так і зовнішньоструктурними зв'язками. Зовнішні структурні прояви злочинності характеризуються багаточисельністю і різноманітністю зв'язків із різними соціальними сферами. Якщо усі процеси і явища, які їі детермінують, уявити у вигляді факторів, то останні 3 деякою втратою інформаційних даних можна класифікувати на чотири групи: 1) фактори демографічного характеру, до яких можна віднести урбанізаційні та міграційні процеси, підвищення чи зниження мобільності населення, зміну його вікової структури тощо; 2) фактори економічного характеру, які пов'язані з рівнем життєзабезпечення та матеріального стану населення; 3) фактори соціального та соціально-психологічного характеру, які включають у себе фактори культурного и освітнього рівня населення, соціальну активність суспільства, громадську думку, рівень соціального контролю тощо; 4) організаційно-правові фактори, які характеризують сферу управління суспільними процесами, які відбуваються в суспільстві [13]. Ми підтримуємо позицію професора В.М. Дрьоміна, який відзначає, що злочинність має властивості відкритої соціальної системи. Системність людській поведінці надають соціальні інститути. Із позиції кримінологічного інституціоналізму підставою для висновку про системність злочинності служить уявлення про неї як інституціоналізовану систему кримінальних практик. Кримінальні практики включені в систему найрізноманітніших соціальних практик і утворюють системні взаємозв'язки і взаємозумовленості. Основним фактором, що дозволяє вважати злочинність системним явищем, $є$ те, що в основі злочинності лежать не кримінально-правові дефініції, а людська діяльність, що реалізується в межах конкретних соціальних відносин [3].

Як відомо, особливості методологічної бази (інструментарію) будь-якого дослідження визначаються специфікою об'єкта, його предметної сфери, а також зумовлені поставленою дослідником метою та завданнями. Під час вивчення злочинності як основного предмета кримінологічної науки необхідно враховувати складні природні та соціальні явища та процеси, які прямо чи опосередковано конструюють сам феномен злочинної поведінки. Дослідницьким об'єктом стає досить широке і сповнене багатьма детермінантами проблемне поле. Воно містить комплекс взаємопов'язаних явищ і процесів, які відбуваються в різноманітних сферах життя суспільства, а також різноманітні характеристики та прояви біосоціальної природи людини. Для дослідження такого широкого і багатопланового поля, враховуючи складність виходу за межі предметної області кримінології, необхідний відповідний методологічний інструментарій, який утворює комплексну дослідницьку програму дослідження злочинності з урахуванням усіх її характеристик [5].

Із точки зору філософії система - це сукупність елементів, які знаходяться у відношеннях і зв'язках один з одним, яка утворює відповідну цілісність і єдність. Загальнонаукова теорія систем передбачає наявність у будь-якій системі переліку властивостей, які повинні бути ій притаманні.

По-перше, наявність структурних елементів (підсистем). Якщо розглядати суспільство як систему, то такими елементами можуть бути соціальні групи, соціальні інститути, особистість.

По-друге, цілісність системи, яка означає впорядкування елементів структури системи, результат процесу внутрішньої організації системи. Через структуру реалізуються властивості, які забезпечують бажане функціонування системи.

По-третє, саморегулювання системи, яке забезпечує функціонування іiї механізмів. Це свого роду фільтри, які підкорюють своїм правилам. Система не пускає у свою структуру «незвичні тіла», саме тому новому елементу необхідно буде або пристосуватись до системи и розпочати існувати за ії правилам, або система його виштовхне. Таким чином, у структурних елементів проходить процес адаптації до системи. 
По-четверте, самовідтворення (самозбереження) - це стійкий процес відтворення структур і зв'язків між ними, постійний процес підтримки рівноваги системи з навколишнім середовищем. Ця властивість системи є базовою, оскільки без неї вона припинить своє існування. Особливо необхідно наголосити, що системі притаманні саме внутрішні ресурси, які забезпечують самовідтворення [9].

Опрацювання матеріалів практики та оцінок стану криміногенної обстановки в установах виконання покарань свідчить про те, що різноманітні форми кримінально-релевантної поведінки та інші явища, які забезпечують вчинення злочинів у місцях позбавлення волі, мають ознаки складної системи. Зважаючи на це, на нашу думку, аналіз сутності злочинності в місцях позбавлення волі слушно здійснювати з використанням інструментарію системного підходу.

Аналізуючи злочинність у місцях позбавлення волі як систему, необхідно виокремити іiі складові частини, встановити та охарактеризувати наявні взаємозв'язки між ії елементами. Так, на нашу думку, систему злочинності в місцях позбавлення волі утворюють: по-перше, злочинність осіб, які відбувають кримінальне покарання у кримінально-виконавчих установах; по-друге, злочинність персоналу органів та установ виконання покарань; no-третє, інфраструктура злочинності в місцях позбавлення волі. Послідовність наукового аналізу вимагає виокремлення основних складових частин вказаних елементів системи.

Так, першим структурним елементом злочинності засуджених у місцях позбавлення волі є злочинна діяльність, спрямована проти встановленого порядку виконання та відбування кримінального покарання: 1) дії, що дезорганізують роботу установ виконання покарань (ст. 392 КК України); 2) злісна непокора вимогам адміністрації установи виконання покарань (ст. 391 КК України); 3) втеча з місць позбавлення волі або з-під варти; 4) масові заворушення, вчинені засудженими в місцях позбавлення волі; 5) погроза або насильство щодо персоналу кримінально-виконавчої установи під час виконання ним службових обов'язків.

Другим структурним елементом злочинності засуджених є злочинна діяльність, пов 'язана з незаконним обігом наркотичних засобів на території установ виконання кримінальних покарань, яка має таку динаміку: 2014 рік - 101 злочин, 2015 р. - 152, 2016 р. - 101, 2017 р. - 93, 2018 р. - 176, 2019 р. - 410 злочинів відповідно.

Наступним структурним елементом є злочинна діяльність проти життя та здоров'я особи, зокрема: 1) умисні вбивства; 2) нанесення тілесних ушкоджень різного ступеня тяжкості.

Четвертим структурним елементом злочинності засуджених в установах виконання кримінальних покарань є корислива злочинна діяльність, зокрема крадіжки.

Наступним структурним елементом такої злочинності є злочинна діяльність, пов'язана 3 незаконним обігом зброї в місиях позбавлення волі.

Аналітичне опрацювання вказаних статистичних даних свідчить, що, незважаючи на зменшення кількості в'язничного населення, відбувається збільшення кількості вчинених злочинів та загальне зростання показників злочинності серед ув'язнених.

Зокрема, у 2017 році в’язнями вчинено 6 умисних вбивств, 7 тяжких тілесних ушкоджень, більшість із яких призвели до смерті потерпілих, майже на 58\% збільшилась кількість самовільних залишень засудженими виправних центрів.

Крім того, відбулося зростання агресії з боку засуджених, про що свідчить збільшення на понад 69\% злочинів, пов'язаних із погрозою або насильством стосовно персоналу виправних закладів.

Так, у 2018 році рівень злочинності зріс на понад 16\% у порівнянні $з$ аналогічним періодом 2017 року та на майже 45\% у порівнянні з 2016 роком (зі 158 до 229 злочинів).

Другим структурним елементом злочинності в місцях позбавлення волі як системи є злочинність персоналу органів та установ виконання кримінальних покарань, яка лише останні роки системно досліджується окремими вченими $[2 ; 4 ; 6 ; 10]$. Опрацювання матеріалів практики дозволяє виокремити у структурі злочинності персоналу органів та установ виконання покарань функціональні підвиди останньої, які виражені у формі злочинної діяльності:

1) злочинна діяльність, спрямована проти життя та здоров'я засуджених, які відбувають кримінальне покарання;

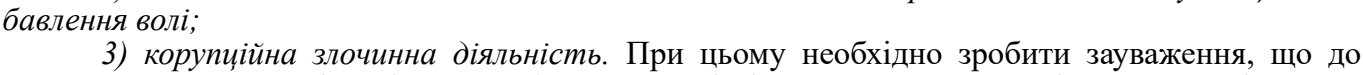
структури злочинності в місцях позбавлення волі відноситься та корупційна злочинність, яка характеризується зв'язком «персонал установи виконання покарання - засуджені», оскільки по- 
ряд із цим працівниками установ виконання покарань вчиняється значна кількість корупційних злочинів поза зв'язком із процесом виконання-відбування кримінального покарання. Можна загалом підтримати позицію дослідників, які відзначають, що корупційна злочинність у ланцюжку «керівництво установи виконання покарань - засуджені» визначається такими незаконними діями посадових осіб виправної установи по відношенню до засуджених за певну винагороду: 1) передача чи спроба передачі заборонених предметів, речей чи продуктів харчування; 2) підготовка та оформлення документів, необхідних для умовно дострокового звільнення від відбування покарання з використанням працівниками свого посадового становища всупереч інтересам служби; 3) незаконне надання різноманітних привілеїв та пільг; 4) інші зловживання, які негативно впливають на діяльність виправних колоній [11].

Наступним структурним елементом злочинності в місцях позбавлення волі є інфраструкmypa. На нашу думку, інфраструктура злочинності - це система суб'єктів та засобів, які не характеризуються чіткими криміногенними ознаками, однак забезпечують злочинну діяльність, а також виступають інструментом взаємодії між злочинністю та соціально-економічними інститутами [14].

Окресливши методологічний підхід щодо можливості розуміння злочинності в місцях позбавлення волі як системи, виокремивши ії структурні елементи, а також динаміку їх розвитку, на нашу думку, необхідно проаналізувати злочинність у місцях позбавлення волі крізь призму ознак, притаманних соціальним системам, які наведені нами вище.

По-перше, злочинність у місцях позбавлення волі має свою внутрішню структуру, яка характеризує її якісні показники та особливості та утворюється з елементів, що знаходяться у взаємодії та мають певну організацію в межах установ виконання покарань.

По-друге, для злочинності в місцях позбавлення волі характерна така ознака цілісності, яка забезпечується окремими інфраструктурними елементами (в'язничною субкультурою, корупційними зв'язками, контролем за УВП із боку лідерів кримінального середовища - «ворів у законі», які знаходяться на волі).

По-третє, необхідно навести класичну догму кримінології, що злочинність - це, перш за все, сукупність злочинів, а не їх проста сума, що відображає взаємозв'язки між ії складовими частинами. Щодо злочинності в місцях позбавлення волі як системи, то ії важливою характеристикою є детермінація ї̈ підвидами один одного в різних формах, що підсилює інтенсивність взаємозв'язків між ними. Так, корупційна злочинність персоналу установ виконання покарань $\epsilon$ однією із ключових умов, що забезпечують наркозлочинність серед засуджених у місцях позбавлення волі. 3 іншого боку, злочинна діяльність засуджених, яка базується на інфраструктурних елементах кримінальної субкультури і спрямована на підтримання злочинного авторитету, зокрема злісна непокора вимогам адміністрації установи виконання покарань, детермінує вчинення персоналом насильницьких злочинів щодо засуджених, що, у свою чергу, в окремих випадках детермінує комплексну злочинну діяльність засуджених - вчинення дій, що дезорганізують роботу установи виконання кримінального покарання, а також масових заворушень в установах виконання покарань.

По-четверте, необхідно відзначити таку ознаку злочинності в місцях позбавлення волі, як самозбереження, що значним чином реалізується через самовідтворення, адаптивність та якісний розвиток. Так, можна відзначити, що, на відміну від злочинності поза межами установ виконання покарань, самозбереження та стабільність злочинності в місцях позбавлення волі як системи забезпечується особливим феноменом - в'язничною субкультурою, яка жорстко структурує кримінальну поведінку засуджених, забезпечує функціонування внутрішньої ієрархії, встановлює «допустимі» реакції на поведінку інших засуджених чи персоналу установ виконання покарань, забезпечує втягнення у злочинну діяльність та кримінальне зараження ув'язнених, які вперше відбувають покарання й ізольовані від суспільства. Інші ознаки, такі як саморозвиток та адаптивність, знаходяться в інтенсивних взаємозв'язках між собою та забезпечують одна одну. Як відзначають дослідники, саморозвиток злочинності характеризується ускладненням злочинної діяльності, отриманням нею нових форм - не лише внаслідок зміни суспільних обставин, які їі зумовлюють, і заходів із боку держави, які застосовуються щодо неї, але також і внаслідок внутрішніх складних процесів взаємодії підсистем і елементів, які утворюють ії структуру [8].

Характеризуючи адаптивність та розвиток злочинності в місцях позбавлення волі як системи, слушно продемонструвати їі на прикладі трансформації окремих складових частин:

1) у частині в'язничної субкультури - зміна правил взаємовідносин між лідерами злочинного середовища в місцях позбавлення волі та представниками адміністрації установи, а в ок- 
ремих випадках - допустимість співпраці між ними, пом'якшення неформальних правил щодо входження до групи лідерів кримінального середовища інших осіб, що забезпечило постійне відтворення керівної ланки кримінального середовища за рахунок молоді та осіб зі значними фінансовими ресурсами тощо;

2) у частині оптимізації окремих форм злочинної діяльності - використання складних соціально-економічних умов у суспільстві, послаблення режиму відбування покарання у вигляді позбавлення волі для формування стійкої та розгалуженої системи корупційних зв'язків із персоналом установ виконання кримінальних покарань, що значно оптимізувало реалізацію окремих форм злочинної діяльності в установах виконання покарань, зокрема незаконний обіг наркотиків та проникнення до установ виконання кримінальних покарань заборонених предметів;

3) у частині появи нових форм злочинної діяльності - вчинення засудженими нових видів кримінальних правопорушень, які є нетрадиційними для місць позбавлення волі.

Висновки. Таким чином, злочинність у місцях позбавлення волі можна розглядати як систему, яка розвивається під впливом внутрішніх і зовнішніх чинників та виступає складовою частиною системи вищого рівня - «злочинності». Ключовими ознаками злочинності в місцях позбавлення волі як системи є: наявність структурних елементів та взаємозв'язків між ними, відносна цілісність, взаємний детермінаційний вплив елементів, самозбереження, адаптивність та здатність до розвитку.

\section{Список використаних джерел:}

1. Бородин С.В. Борьба с преступностью: теоретическая модель комплексной программы. Москва : Наука, 1990. 272 с.

2. Дробатюк О.П. Латентність злочинів, вчинених персоналом установ виконання покарань в Україні: Держава та регіони. Серія: Право. 2014. № 3. С. 84-88

3. Дрьомін В.М. Інституційна теорія злочинності та криміналізація суспільства дис... докт. юрид. наук : 12.00.08. Одеса, 2010. 428 с.

4. Журавська 3.В. Основні детермінанти протиправної поведінки персоналу виправних колоній. Часопис Київського університету права. 2013. № 3. С. 296-300.

5. Игнатов А.Н., Ильянович Е.Б. Методологические основы исследования преступности. Общество и право. 2015. № 2. С. 129-133

6. Колб I.О. Про деякі віктимологічні аспекти вчинення злочинів персоналом Державної кримінально-виконавчої служби України під час застосування заходів приборкання засуджених. Науковий вісник Ужгородського національного університету. 2019. Випуск. 54. С. 152-155.

7. Кондаков Н.И. Логический словарь-справочник. 2-е изд., испр. и доп. Москва : Наука, 1976.

8. Макаров В.В. Преступность как система: институциональные проблемы. Российский следователь. 2013. № 23. С. 31-34.

9. Матюшенко С.В., Нагаева А.И. Свойства преступности с позиции системного подхода в криминологии. Национальнье приоритеть России. 2015. № 1. С. 21-24.

10. Руденко B.I. Мотиви вчинення злочинів персоналом установ виконання покарання України: поняття та запобігання їх реалізації на практиці : дис... канд. юрид. наук : 12.00.08. Запоріжжя. 2018. 330 c.

11. Сивцов С.А. Коррупционные преступления в исправительных колониях России и механизм противодействия им : автореф. дис... канд. юрид. наук : 12.00.08. Саратов, 2017. 20 с.

12. Синилов Г.К. О некоторых итогах развития теории оперативно-розыскной деятельности за последние 15 лет (1990-2005) и ее актуальных проблемах на ближайшую перспективу. Оперативник (Сыщик). 2005. № 3. С. 11-16

13. Сутурин М.А. Преступность как система. Сибирский юридический вестник. 2005. № 4. C. $62-67$.

14. Цехан Д.М. Інфраструктура злочинності: теоретичний аналіз. Вісник Київського Національного університету імені Тараса Шевченка. 2015. № 2. С. 53-56. 